\section{Highly sensitive microplate $\beta$-galactosidase assay for yeast two-hybrid systems}

\author{
Laurence Brouchon-Macari, Marie-Claire Joseph, and Marie-Claire Dagher \\ Laboratoire de Biochimie et Biophysique des Systèmes Intégrés, Grenoble, France
}

BioTechniques 35:446-448 (September 2003)
The yeast two-hybrid system is a powerful tool to monitor protein-protein interactions. It relies on the expression of hybrid proteins in the yeast nucleus and the activation of reporter genes when a hybrid transcription factor (e.g., Gal4) is reconstituted via two interacting proteins (1). The method has been used at the genome level in organisms ranging from viruses to plants to assess protein-protein interaction networks using prototrophy markers as reporter genes (2-4). A second reporter gene, $L a c Z$, offers the possibility of quantitative measurements of $\beta$-galactosidase activity by a colorimetric method (5). A $\beta$-galactosidase test in bacteria has been transposed to microplates (6). In the case of yeast, the conditions for cell lysis in microplates have been improved $(7,8)$, but for truly high-throughput twohybrid tests $(4,9,10)$, the $\beta$-galactosidase reporter activity is still assayed in test tubes. In this report, we have successfully adapted yeast culture, permeabilization, and $\beta$-galactosidase assay conditions to microtiter format, and the optimization of all these steps led us to increase the sensitivity of the enzyme assay by at least 50-fold compared to classical methods. Direct kinetic recording instead of end point measurements allows for the processing of high- and low-activity samples in the same plate with good reproducibility. The colorimetric assay costs apis about 200-fold less expensive than a commercially available $\beta$-galactosidase assay kit. The method can be used for the various types of yeast two-hybrid systems currently in use.

To set up the method, we used a twohybrid system in which the DNA-binding domain was the LexA protein from Escherichia coli that has been previousproximately $\$ 200 / 1000$ plates, which ly described (11) in L40 strain. We then extended the method to the other LexAbased system (12) in EGY48 strain with reporter plasmid pSH18:34 and to a system in which the DNA-binding domain was the DNA-binding domain of the yeast transcription factor Gal4 itself (BD Biosciences Clontech, Erembodegem, Belgium) in Y190 strain. The two-hybrid systems and yeast strains have been previously described (13). Yeast cells expressing interacting pairs were grown in glucose medium (galactose in the case of Reference 12) with appropriate selection. With the classical approach, to assess the reporter gene HIS3 (or LEU2), yeast patches were replicated on agar medium that lacked the appropriate amino acids, and growth was visualized after $48 \mathrm{~h}$ (Figure 1A). The reference method for the $\beta$-galactosidase assay was a filter test, using $\mathrm{X}$-gal as a substrate (5), in which a blue coloration developed in 1-10 h (Figure 1B). To adapt the test to microplates, we modified several steps. Yeast culture was made in microplate format instead of culture tubes. Culture medium (0.5 $\mathrm{mL}$ ), consisting of $2 \%$ glucose, $6.7 \mathrm{~g} / \mathrm{L}$ yeast nitrogen base without amino acids, supplemented with an amino acid mixture lacking the appropriate amino acids for selection (Qbiogene S.A., Illkirch, France), was inoculated with a toothpick from a patch on agar plates, and yeast cells were cultured in deep-well, conical-bottom microplates (Eppendorf, Le Peck, France) in a thermoblock shaker with a microplate holder. We found the Thermomixer Comfort model (Eppendorf) provided the vigorous shaking (900 rpm) needed to prevent the yeast
Table 1. Protocol for the Assay of $\beta$-Galactosidase Activity in Microplates

\section{Yeast Culture}

1. To inoculate, transfer from a solid culture plate to $0.5 \mathrm{~mL}$ medium with appropriate amino acid selection.

2. Culture for $20 \mathrm{~h}$ with shaking in a deep-well, conical-bottom microplate.

3. Dilute $50 \mu \mathrm{L}$ culture in $1 \mathrm{~mL}$ medium.

4. Culture for $48 \mathrm{~h}$ at $30^{\circ} \mathrm{C}$

\section{$\beta$-Galactosidase Assay}

1. Transfer $200 \mu \mathrm{L}$ culture into a U-bottom microplate.

2. Quantify yeast cells by absorbance at $590 \mathrm{~nm}^{\mathrm{a}}$.

3. Centrifuge the microplate at $1500 \times g$.

4. Discard supernatant fractions.

5. Add $100 \mu \mathrm{L} 100 \mathrm{mM}$ sodium phosphate ${ }^{\mathrm{b}}$ buffer, $\mathrm{pH} 7.5$, containing $0.1 \%$ sodium dodecyl sulfate.

6. Shake at $800 \mathrm{rpm}$ for $10 \mathrm{~min}$ at $30^{\circ} \mathrm{C}$.

7. Add 2.5 mM o-nitrophenyl- $\beta$-D-galactopyranoside (ONPG) in $25 \mu \mathrm{L}$.

8. Measure absorbance at $414 \mathrm{~nm}$ in an iEMS microplate reader for $10 \mathrm{~min}$ at $30^{\circ} \mathrm{C}$ to obtain kinetic recording.

9. Determine $\beta$-galactosidase activity from linear part of ONPG hydrolysis curve ${ }^{\mathrm{C}}$.

$\mathrm{a}_{1.0} \times \mathrm{A}_{590}=6 \times 10^{6}$ yeast cells.

${ }^{\mathrm{b}}$ Consisting of $82 \mathrm{mM} \mathrm{Na}_{2} \mathrm{HPO}_{4}$ and $12 \mathrm{mM} \mathrm{NaH}_{2} \mathrm{PO}_{4}$.

${ }^{c} \beta$-galactosidase unit: increase in absorbance at $414 \mathrm{~nm} \times \mathrm{min}^{-1} \times 1000 /\left(\mathrm{A}_{590}\right)$. 
from settling. Aeration was assured via a plastic gas-permeable lid. The culture time was found to greatly affect $\beta$-galactosidase activity, and an optimal culture time of $48 \mathrm{~h}$ at $30^{\circ} \mathrm{C}$ was determined. After $20 \mathrm{~h}, 50 \mu \mathrm{L}$ of the yeast suspension were diluted in $1 \mathrm{~mL}$ fresh medium. For the assay, $0.2 \mathrm{~mL}$ of the yeast suspension were transferred to U-bottom plates and quantified by reading the absorbance at $590 \mathrm{~nm}$ in a microplate reader (iEMS Labsystem; Thermo Life
Science France S.A., Cergy Pontoise, France). Approximately $6 \times 10^{6}$ yeast cells, corresponding to an absorbance of 1.0, were used in each assay. The microplate was centrifuged at $1500 \times g$ in a CR-4.12 centrifuge (Jouan S.A., St. Herblain, France) with a M4 rotor for 5 min, and the supernatant was discarded. Permeabilization was performed in 100 $\mu \mathrm{L} 100 \mathrm{mM}$ sodium phosphate buffer containing sodium dodecyl sulfate (SDS) (instead of 5\% chloroform) by
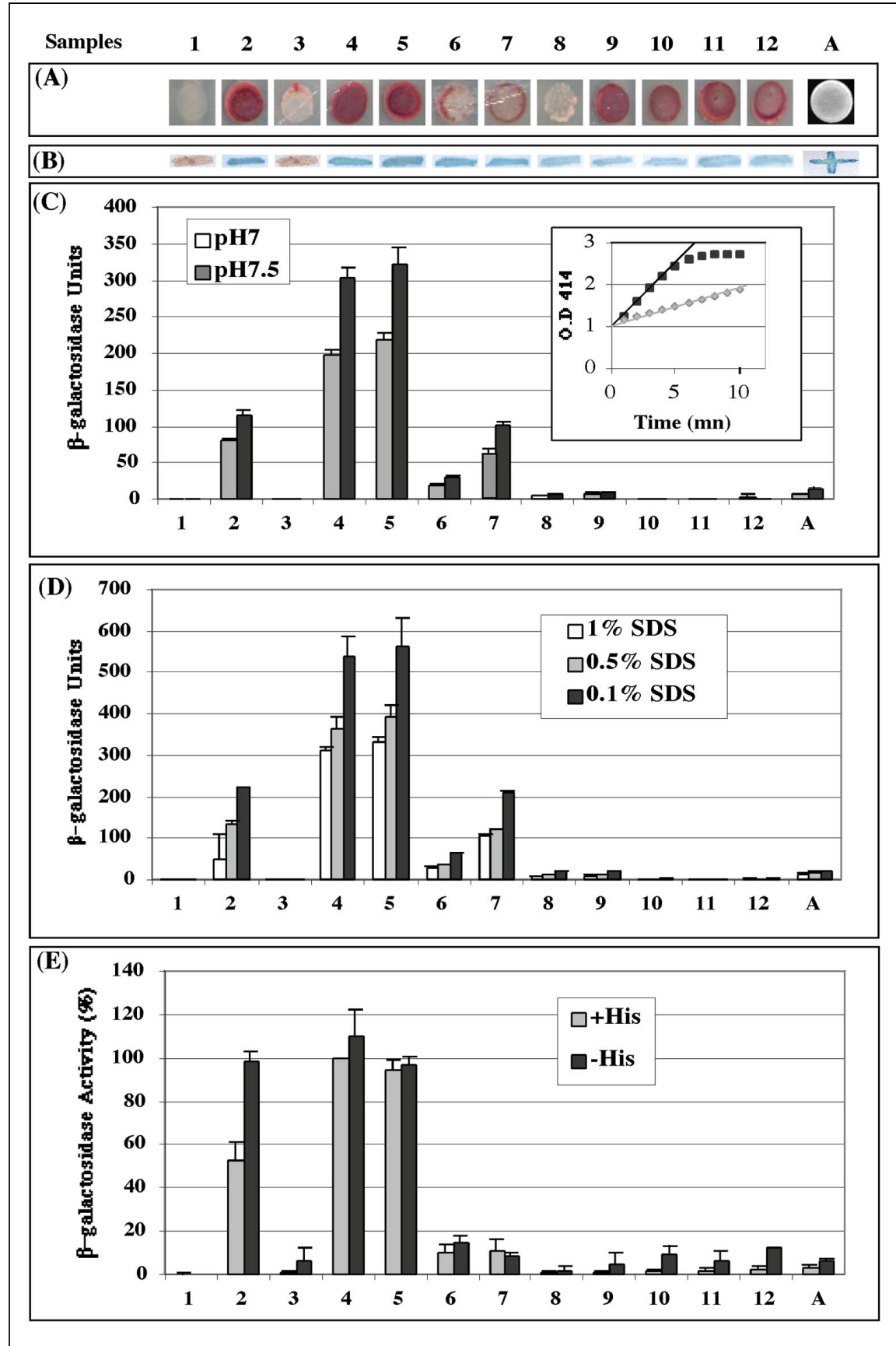

shaking for $10 \mathrm{~min}$ at $800 \mathrm{rpm}$ at $30^{\circ} \mathrm{C}$. Because of possible precipitation, we omitted $\mathrm{KCl}$. We also found that $\mathrm{Mg}^{2+}$ and $\beta$-mercaptoethanol were unnecessary (data not shown). The SDS solution (10\%) was purchased from Invitrogen, Cergy Pontoise, France. Other chemicals and o-nitrophenyl- $\beta$-D-galactopyranoside (ONPG) were purchased from Sigma-Aldrich, Saint Quentin Fallavier, France. The reaction was initiated by the addition of $2.5 \mathrm{mM}$ ONPG in $25 \mu \mathrm{L}$,
Figure 1. Comparison between qualitative reporter gene expression and our new quantitative $\beta$-galactosidase assay. A series of interacting pairs in the LexA-based two-hybrid system (11) (numbered from 2 to 12,1 being the negative control with one empty vector) were tested under several conditions. Sample A corresponds to Gal4-based two-hybrid system positive control. The $\beta$-galactosidase activity is expressed in units (see Table 1). The same samples are used in all panels. (A) Assay of the reporter HIS3 by growth on solid selective medium lacking histidine (His). (B) Qualitative assay of the reporter gene $L a c Z$ using $\mathrm{X}$-gal as a substrate. The test was made on filter papers as previously described (5). The blue coloration developed between 1 and $10 \mathrm{~h}$. (C) Comparison of $\mathrm{pH} 7.0$ (gray bars) and $\mathrm{pH} 7.5$ (black bars) for the sodium phosphate buffer in the quantitative $\beta$-galactosidase assay. The result of one representative experiment (of five) is shown. All assays were run in triplicate. Insert: direct curves of the kinetics of o-nitrophenyl- $\beta$-D-galactopyranoside (ONPG) hydrolysis followed at $414 \mathrm{~nm}$. The crude data correspond to sample no. 5, pH 7.5 (black squares), and sample no. 2, pH 7.0 (gray diamonds). (D) Effect of sodium dodecyl sulfate (SDS) concentration used for permeabilization on $\beta$-galactosidase activity. The $\mathrm{pH}$ of the sodium phosphate buffer was set to 7.5 , and concentrations of SDS of $1 \%$ (white bars), $0.5 \%$ (gray bars), or $0.1 \%$ (black bars) were added. Each column in the histogram corresponds to a representative experiment (run in triplicate) from five experiments. (E) Comparison of $\beta$-galactosidase activity after growth in selective (-His) or nonselective (+His) medium. The yeast cells were diluted in selective medium (-His, black bars) or nonselective medium (+His, white bars). The optimal assay conditions, sodium phosphate buffer, $\mathrm{pH} 7.5$, and $0.1 \%$ SDS, were used. Data were taken from three independent experiments that were normalized to $100 \%$ because of slight differences in yeast growth. Results are expressed as the mean $(\bar{x})$, and the error bars represent the standard error of the mean (SEM). The maximal activity corresponds to $745 \beta$-galactosidase units. In the case of the Gal4-based sample $\mathrm{A}$, the maximal activity is $44 \beta$-galactosidase units. The activities for two samples in the LexA/EGY48/ pSH18:34 system (12) were 50 and $1463 \beta$-galactosidase units, respectively (data not shown). 
and absorbance at $414 \mathrm{~nm}$ was recorded for $10 \mathrm{~min}$. The kinetics of ONPG hydrolysis was taken from the linear part of the curve for the determination of $\beta$-galactosidase units. The original method (14) was an end point method with an addition of sodium carbonate to stop the reaction and to enhance the yellow coloration of hydrolyzed ONPG. With the modifications to the protocol, the kinetics of ONPG hydrolysis could be directly followed at $414 \mathrm{~nm}$ in each well simultaneously. For each well, the linear part of the curve was taken into consideration (see insert to Figure 1C). We checked that the slight turbidity of the reaction medium had no effect on the kinetics and concluded that centrifugation was unnecessary. The key to the method was the improved sensitivity that allowed us to confidently reveal the activity by the quantitative method, even for the weakly positive interacting pairs (see data for sample A, which is representative of the less sensitive Gal4based two-hybrid system). The figure shows stepwise improvements in sensitivity on the same series of interacting pairs. First, we compared the activities at two standard buffer $\mathrm{pH}$ values found in the literature $(14,15)$ and determined that 7.5 was the optimum $\mathrm{pH}$ (Figure 1C). Second, at $\mathrm{pH} 7.5$, reducing the concentration of SDS from $1 \%$ to $0.1 \%$ increased the activity (Figure 1D). Third, at pH 7.5 and with $0.1 \%$ SDS, culture in selective medium lacking histidine (His; in systems where HIS3 is a reporter gene) increased the sensitivity (Figure 1E). Moreover, when the $\beta$-galactosidase data are normalized to compensate for growth differences, the reproducibility among three independent experiments is good for samples with high activities as well as for samples with low activities (Figure 1E), with a standard error of less than $10 \%$. Table 1 describes the final protocol.

In conclusion, we have developed a quantitative and highly sensitive twohybrid test that allows for the simultaneous assay of 96 interactions, even when they are relatively weak. It should be mentioned that quantitative data do not directly reflect affinities because the activation of reporter genes also depends on the level of the expression of the two-hybrid proteins. Our test is inexpensive, compared to commercially available yeast $\beta$-galactosidase assay kits, and suited to high-throughput twohybrid systems currently in use. Moreover, it can be used in high-throughput screening for compounds that affect a specific interaction with minimal manipulation and only one centrifugation step. Another possibility is to use this test to assess the ability of a third partner introduced by transformation or mating procedures (triple hybrid) to enhance or to inhibit a previously characterized two-hybrid interaction.

\section{ACKNOWLEDGMENTS}

The authors thank Drs. Rabiet, Willison, and Griffin-Shea for their critical reading of the manuscript.

\section{REFERENCES}

1.Fields, S. and O. Song. 1989. A novel genetic system to detect protein-protein interactions. Nature 340:245-246.

2.Mendelsohn, A.R. and R. Brent. 1994. Applications of interaction traps/two-hybrid systems to biotechnology research. Curr. Opin. Biotechnol. 5:482-486.

3.Legrain, P., J. Wojcik, and J.M. Gauthier. 2001. Protein-protein interaction maps: a lead towards cellular functions. Trends Genet. 17: 346-352.

4.Fang, Y., D.J. Macool, Z. Xue, E.P. Heppard, C.F. Hainey, S.V. Tingey, and G.H. Miao. 2002. Development of a high-throughput yeast two-hybrid screening system to study proteinprotein interactions in plants. Mol. Genet. Genomics 267:142-153.

5.Transy, C. and P. Legrain. 1995. The twohybrid: an in vivo protein-protein interaction assay. Mol. Biol. Rep. 21:119-127.

6.Griffith, K.L. and R.E.J. Wolf. 2002. Measuring $\beta$-galactosidase activity in bacteria: cell growth, permeabilization, and enzyme assays in 96-well arrays. Biochem. Biophys. Res. Commun. 290:397-402.

7.Schneider, S., M. Buchert, and C.M. Hovens. 1996. An in vitro assay of $\beta$-galactosidase from yeast. BioTechniques 20:960-961.

8.LeGuevel, R. and F. Pakdel. 2001. Streamlined $\beta$-galactosidase assay for analysis of recombinant yeast response to estrogens. BioTechniques 30:1000-1004.

9.Cagney, G., P. Uetz, and S. Fields. 2000. High-throughput screening for protein-protein interactions using two-hybrid assay. Methods Enzymol. 328:3-14.

10.Walhout, A.J.M. and M. Vidal. 2001. Highthroughput yeast two-hybrid assays for largescale protein interaction mapping. Methods 24: 297-306.

11.Fuchs, A., M.-C. Dagher, and P.V. Vignais. 1995. Mapping the domains of interaction of p40phox with both p47phox and p67phox of the neutrophil oxidase complex using the twohybrid system. J. Biol. Chem. 270:5695-5697.

12.Estojak, J., R. Brent, and E.A. Golemis. 1995. Correlation of two-hybrid affinity data with in vitro measurements. Mol. Cell. Biol. 15:5820-5829.

13.Dagher, M.-C. and O. Filhol-Cochet. 1996. Making hybrids of two-hybrid systems. BioTechniques 22:916-922.

14.Miller, J.H. 1972. Assay of $\beta$-galactosidase, p. 352-355. In Experiments in Molecular Genetics. CSH Laboratory Press, Cold Spring Harbor, NY.

15.Sambrook, J., E.F. Fritsch, and T. Maniatis (Eds.). 1989. Expression of cloned genes in cultured mammalian cells, p. 16.26. In Molecular Cloning: A Laboratory Manual. CSH Laboratory Press, Cold Spring Harbor, NY.

Received 28 February 2003; accepted 16 May 2003.

Address correspondence to Marie-Claire Dagher, Département Réponse et Dynamique Cellulaire (DRDC), Laboratoire de Biochimie et Biophysique des Systèmes Intégrés (BBSI), CEA Grenoble, 17 Rue des Martyrs, 38054 Grenoble cedex 9 France. e-mail:mcdagher@cea.fr 